\title{
Pamuk Arzını Etkileyen Faktörlerin Panel Veri ile Analizi:
} 2000-2015

Pamuk Arzını Etkileyen Faktörlerin Panel Veri ile Analizi: 2000-2015

Öz

Birçok sektör için lokomotif görevi gören pamuk, ülke ekonomilerinde önemli bir yere sahiptir. Bu önemine rağmen üreticileri kar maksimizasyonu hedeflerine ulaştıramadığı için son dönemde yerini alternatif ürünlere bırakmaya başlamıştır. Türkiye'nin ekolojik yapısı, dünya üretimindeki yeri ile rekabet gücü ve pamuğun beslediği diğer sektörler dikkate alındığında pamuk üretimine gereken önemin verilmesi gerekliliği ön plana çıkmaktadır. Bu nedenle çalışmanın amacı, heterojen bir yapıya sahip olan pamuğun arz fonksiyonunu etkileyen faktörler Türkiye üretiminin yaklaşık yüzde doksan beşini karşılayan dört üretim bölgesi ana çatısında incelemektir. 2000-2015 dönemine ait yıllık verilerin kullanıldığı çalışmada panel veri yöntemi uygulanmış olup, analiz sonucunda arz esnekliği pozitif, çapraz fiyat esnekliğinin ise negatif olduğu tespit edilmiştir.
Panel Data Analysis of the Factors Affecting Cotton Supply: 2000-2015

\section{Abstract}

Cotton which acts as a locomotive for many industries has a significant place in national economies. Despite this significance, it began to be substituted by alternative products as it couldn't provide the producers to achieve their profit maximization targets. When ecological structure of Turkey, its position and competitiveness in global production and other sectors supported by cotton are taken into consideration the necessity to give the required importance to cotton production comes to the fore. Therefore the aim of this study is to examine the factors affecting the supply function of cotton which has a heterogeneous structure under the framework of four production regions which meets approximately ninety five percent of cotton production in Turkey. Panel data method was implemented in the study which used annual data of the period 2000-2015 and as a result of the analysis it was determined that supply elasticity was positive and cross-price elasticity was negative.

\section{Giriş}

Anadolu'ya 1900 yıl önce Hindistan'dan getirilen pamuk, Bizans, Selçuklu ve Osmanlı dönemlerinde yetiştirilmeye başlanmış ve bu dönemde pamuk yetiştiricilerine her türlü destek verilerek üretiminin artırılması amaçlanmıştır. Bu gelişmenin bir sonucu olarak Bursa, Konya, Sivas, Edirne, Sinop, Balıkesir pamuk tarımında önemli merkez haline gelmiştir. Pamukta yaşanan diğer önemli bir gelişme ise kurumsal düzenlemelerin bir sonucu olarak Cumhuriyet döneminde yaşanmıştır.

Türkiye ekonomisinde yarattığı istihdam, katma değer vb. katkıları ile önemli bir yere sahip olan pamuk, Türkiye'nin ekolojik yapısı gereği çoğunlukla Ege, Çukurova, Güneydoğu Anadolu Bölgesi ile Antalya yöresi ve Marmara Bölgesinin batı ve doğu kesimlerinde yetiştirilmektedir. Ancak zaman içerisinde yaşanan iklim değişikliği ve alternatif ürünlerin cazibesi nedeniyle pamuk üretiminin özellikle Batı ve Doğu Marmara bölgesinde yerini alternatif ürünlere bıraktığı görülmektedir. 2015 yılı itibari ile 779 bin ton olan pamuk üretiminin yaklaşık \% 95'i Ege, Çukurova, Güneydoğu Anadolu Bölgesi ile Antalya yöresi tarafından gerçekleştirilmektedir (TÜik, https://biruni.tuik.gov.tr). Dolayısıyla bu dört bölgenin Türkiye'nin pamuk ihtiyacını

\footnotetext{
${ }^{1}$ Yrd. Doç. Dr., Mehmet Akif Ersoy Üniversitesi iỉF, İktisat Bölümü. konder@mehmetakif.edu.tr
} 
karşıladığı ifade etmekle birlikte, bölgelerde yapılan ürün kalitesi bölgeden bölgeye farklılıklar göstermektedir. Bu nedenle bu çalışmanın amacl; Türkiye geneline yönelik pamuk arz fonksiyonu oluşturmak yerine farklı bölgede farklı kalitede üretilen ürünün arzını etkileyebilecek faktörlerin farklı olabileceği gerçeğinden yola çıkarak bölgesel pamuk arzı fonksiyonlarını incelemektir. Ayrıca ulusal ve uluslararası yazın incelendiğinde, pamuk arzını etkileyen faktörleri ele alan çalışmaların çok az olduğu ve uluslararası yazında yer alan çok az çalışmada panel veri yönteminin kullanıldığı ve bunların çok azında da Türkiye'ye yer verildiği görülmektedir. Ulusal yazın incelendiğinde ise yok denecek kadar az çalışmanın yapıldığı, bu çalışmaların da Türkiye geneline yönelik ve zaman serileri ile veya lojistik regresyon modelleri yardımı ile yapıldığı görülmektedir. Bu nedenle bu çalışmada, literatürdeki diğer çalışmalardan farklı olarak panel veri yöntemi kullanılacak ve yine ürüne yönelik bölgesel ürün farklılığı dikkate alınarak ulusal yazında var olan boşluğu doldurmak amacı ile bölgesel bazda 2000-2015 dönemine ait yıllık verilerin ışığı altında Ege, Akdeniz, Güneydoğu Anadolu ile Marmara Bölgesine ait pamuk arz fonksiyonu panel veri yöntemi ile analiz edilecektir. Çalışma üç bölümden oluşmakta olup, birinci bölümde pamuğun Türkiye ekonomisindeki yerinden bahsedilecek, ikinci bölümde literatür çalışmalarına yer verilecek, üçüncü bölümde kullanılan veri seti ve yöntemden bahsedilecek ve takip eden bölümde ise ampirik çalışma sonucu elde edilen sonuçlara yer verilerek sonuçlarla ilgili değerlendirme yapılacaktır.

\section{Pamuk Üretiminin Türkiye'deki Yeri ve Önemi}

Pamuk, tekstil sektörü başta olmak üzere elliye yakın sanayi kolunun hammaddesini oluşturan en önemli tarımsal ürünlerden birisidir. Ayrıca pamuk, ekonomiye sağladığı katma değerin yanı sıra emek yoğun işgücü kullanımından kaynaklı olarak ekonomiye geniş istihdam imkânı da sunmaktadır. Bu nedenle pamuk, nüfus artışı ve yaşam standartlarının yükselmesi ile dünya çapında pamuğa duyulan ihtiyacı ve buna bağlı olarak da talebi artırmaktadır (iTO, 2003:2-14; TZOB, 2004: 1-4).

Dünya ülkelerinin ekolojik yapısı incelendiğinde az sayıda ülkenin pamuk üretimine elverişli olduğu, bu nedenle dünya üretiminin \%80'ine yakını Türkiye'nin de içinde bulunduğu az sayıda ülke tarafından gerçekleştirildiği görülmektedir (Tablo 1) (Gümrük ve Ticaret Bakanlığı, 2014:3).

Tablo 1: 2015 Yılı Dünya Lif Pamuk Üretimi ve Tüketimi (Milyon Ton)

\begin{tabular}{lclc}
\hline Ülkeler & Üretim & Ülkeler & Tüketim \\
\hline Hindistan & 6.480 & Çin & 8.000 \\
Çin & 5.742 & Hindistan & 5.270 \\
ABD & 3.259 & Pakistan & 2.365 \\
Pakistan & 2.035 & Türkiye & 1.441 \\
Brezilya & 1.544 & Bangladeş & 992 \\
Özbekistan & 940 & Brezilya & 859 \\
Türkiye & 779 & ABD & 840 \\
Avusturalya & 499 & Vietnam & 825 \\
Türkmenistan & 263 & Endonezya & 744 \\
Diğer & 2.991 & Diğer & 3.350 \\
\hline Toplam & 24.565 & Toplam & 24.686 \\
\hline
\end{tabular}

Kaynak: ICAC, https://icac.generation10.net/statistics/index 
Dünyanın en büyük pamuk üreticisi ülkesi olan Çin, dünya pamuk üretiminin $\% 26$ 'sını gerçekleştirmektedir. Çin'i \%17,72'lik oranı ile ABD takip etmektedir. Bu ülkeleri sırası ile Hindistan, Pakistan ve Özbekistan izlemektedir. Türkiye ise pamuk ekimi yapılan yaklaşık 779 bin ton pamuk üretimi ve \%3,2'lik payı ile dünyanın yedinci büyük pamuk üreticisi konumundadır. Dünya tüketim değerleri incelendiğinde; dünyada en çok pamuk tüketen ülkelerin en çok üretim payına ve pamuğu işleme kapasitesine sahip (Çin, Hindistan ve Türkiye gibi) ülkeler olduğu görülmektedir (Gümrük ve Ticaret Bakanlığı, 2012). 2015 döneminde 24,4 milyon ton düzeylerinde seyreden dünya pamuk tüketiminin yaklaşık 1,5 milyon tonluk tüketim değeri ile Türkiye tarafından gerçekleştirilerek dünyanın en çok pamuk tüketen 4'üncü büyük ülkesi konumundadır (ICAC, www.icac.org).

Pamuk sektöründe sürekli Çin, Hindistan ve Pakistan ile rekabet içerisinde olan Türkiye, ekonomisinde önemli bir yere sahip olan pamuk üretimi için gerekli ekolojik şartlara sahiptir. Türkiye'de pamuk üretimi yoğun olarak Ege Bölgesi, Çukurova, Güney Doğu Anadolu Bölgesi ve Antalya yörelerinde yapılmaktadır (Tablo 2). Bölgesel bazda son 20 yıllık süreç incelendiğinde; Güney Doğu Anadolu Bölgesi hariç her yıl bütün bölgelerde pamuk üretiminin düştüğü dikkati çekmektedir. Türkiye'nin 1995 yılında 75,7 milyon hektar alan olan pamuk ekim alanı, 2015 yılında \%43 oranında azalarak 43,4 milyon hektar alana gerilemiştir. Bu alanın \%61,1'i Güneydoğu Anadolu Bölgesinde gerçekleştirilirken, \%21,2'si Ege Bölgesinde ve \%17,9'u ise Akdeniz Bölgesinde yapılmaktadır. (Gümrük ve Ticaret Bakanlığı, 2015:4)

Tablo 2: Bölgeler Itibariyle Türkiye Pamuk Ekim Alanları (Milyon Ha) ve Üretim Miktarı (Bin Ton)

\begin{tabular}{|c|c|c|c|c|c|c|c|c|c|c|}
\hline \multirow[t]{2}{*}{ YII } & \multicolumn{2}{|c|}{ Ege } & \multicolumn{2}{|c|}{ Akdeniz } & \multicolumn{2}{|c|}{ G.Doğu Anado- } & \multicolumn{2}{|c|}{ Marmara } & \multicolumn{2}{|c|}{ Toplam } \\
\hline & $\begin{array}{c}\text { Ekim } \\
\text { Ala- }\end{array}$ & Üretim & $\begin{array}{l}\text { Ekim } \\
\text { Alan }\end{array}$ & Üretim & $\begin{array}{l}\text { Ekim } \\
\text { Alanı }\end{array}$ & Üretim & $\begin{array}{l}\text { Ekim } \\
\text { Alanı }\end{array}$ & Üretim & $\begin{array}{l}\text { Ekim } \\
\text { Alanı }\end{array}$ & Üretim \\
\hline 1995 & 24,9 & 74,1 & 27,3 & 84,9 & 20,4 & 60,0 & 3,0 & 3,0 & 75,7 & 222,0 \\
\hline 2000 & 20,2 & 68,4 & 12,3 & 44,6 & 31,7 & 111,6 & 1,3 & 1,4 & 65,4 & 226,0 \\
\hline 2005 & 13,8 & 52,6 & 10,9 & 51,9 & 29,5 & 117,9 & 0,5 & 1,5 & 54,7 & 223,9 \\
\hline 2010 & 8,3 & 37,7 & 10,6 & 55,1 & 28,8 & 122,1 & 0,4 & 0,1 & 48,1 & 215,0 \\
\hline 2011 & 9,7 & 45,4 & 11,4 & 67,6 & 31,4 & 179,7 & 0,6 & 0,5 & 53,0 & 293,2 \\
\hline 2012 & 8,3 & 40,9 & 9,1 & 52,3 & 30,2 & 152,9 & 0,6 & 0,3 & 48,2 & 246,4 \\
\hline 2013 & 8,3 & 70,1 & 7,9 & 48,3 & 27,8 & 152,2 & 0,6 & 0,1 & 44,6 & 270,7 \\
\hline 2014 & 9,3 & 51,2 & 7,5 & 46,1 & 28,9 & 137,7 & 0,6 & 0,1 & 46,4 & 235,2 \\
\hline 2015 & 9,2 & 46,2 & 7,2 & 40,3 & 26,5 & 135,4 & 0,6 & 0,1 & 43,4 & 221,9 \\
\hline
\end{tabular}

Kaynak: TÜiK, https://biruni.tuik.gov.tr/bitkiselapp/bitkisel.zul

Üretim alanları incelendiğinde; pamuk ekim alanlarının zaman içinde artış ve azalış göstermesine rağmen genel trendin azalış yönünde olduğu görülmektedir. Pamuğun ekim alanlarında yaşanan daralmanın temelinde; rakip ülkelerin ucuz hammadde, iş̧ilik ve enerji fiyatlarının bir sonucu olarak pamuk üretim maliyetinin rakiplerine kıyasla yüksek olması ve rekabetin zorlaşması, bu ülkelerdeki makineleşme ve verim düzeyi yüksek tohumların kullanımı ve pamuk üretimi yapılan özellikle Ege ve Çukurova bölgelerinde üreticinin üretim yapabileceği alternatif ürün çeşitliliğinin fazla olması ve Çin gibi pamuk üretiminde önemli bir yere sahip olan ülkelerin uyguladığı pamuk stok politikalarının ürün fiyatı üzerindeki etkisinin bir sonucu olarak yurt içi fiyatların düşük seyretmesi gibi faktörler yer almaktadır (Gümrük ve Ticaret Bakanlığı, 2012, 2013, 2014, 2015). Ayrıca, Türkiye'de yaşanan özellikle de 2007 yılında görü- 
len kuraklık ile finansal ve ekonomik krizler pamuk üretimini olumsuz yönde etkilemiştir. 2008 yılında yaşanan küresel ekonomik kriz de pamuk üretiminin yanı sıra tüketimini de olumsuz yönde etkilemiştir. Krizin etkisi Türkiye ile sınırlı kalmamış rakiplerini de aynı yönde etkisi altına almıştır. 2011-2012 döneminde pamuk fiyatlarında yaşanan tarihi seviyenin sonucu olarak Türkiye dahil tüm dünyada pamuk üretimi artmıştır. Takip eden dönemde yaşanan fiyat gevşemesi ile birlikte bu yükseliş yerini üretimde gerilemeye bırakmıştır (Gümrük ve Ticaret Bakanlığı, 2014: 7).

Birçok sektörün hammadde lokomotifi olarak görülen pamuğun tüketim seyri incelendiğinde; pamuktan girdi olarak beslenen sektörlerde yaşanan gelişmelere paralel olarak pamuk tüketiminin artış trendi gösterdiği görülmektedir (Grafik 1).

Grafik 1. Türkiye Lif Pamuk Üretimi ve Tüketimi (Bin Ton)

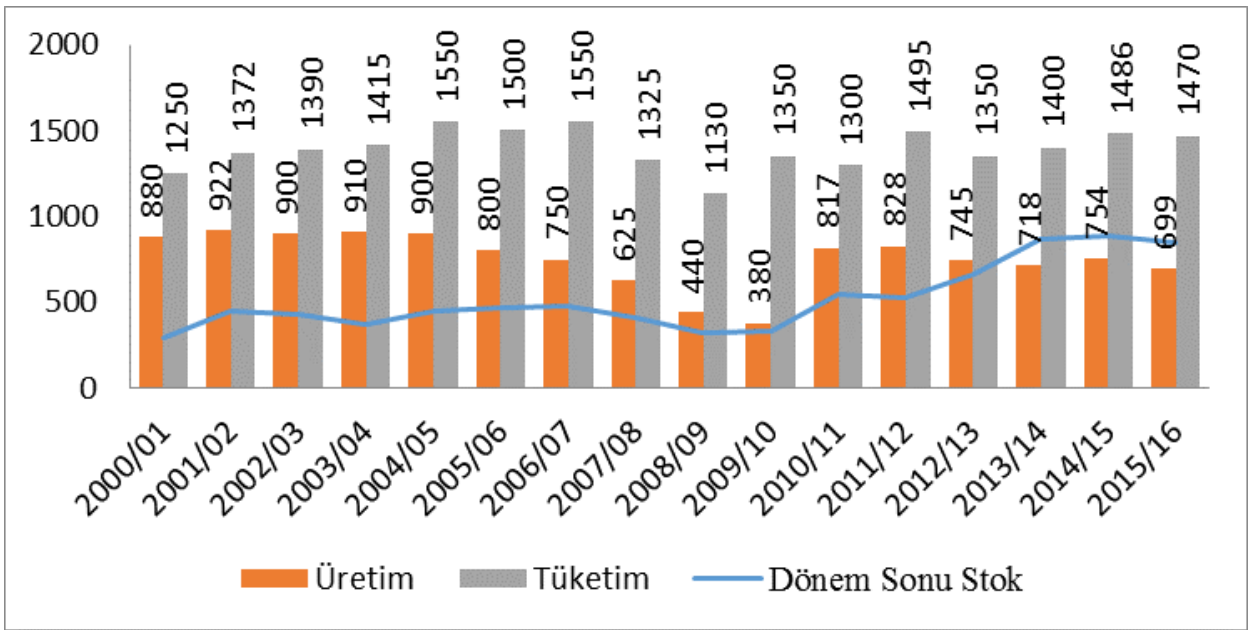

Kaynak: ICAC, https://icac.generation10.net/statistics/index

Yaklaşık 15 yıl önce 1250 bin ton olan toplam pamuk tüketimi zaman içerisinde artış göstermiş ve 2015/16 döneminde 1470 bin tona yükselmiştir. Yıllar itibariyle pamuk tüketiminde dikkat çeken önemli bir husus da pamuk tüketiminde ortaya çıkan artışının dönem sonu stok artışından fazla olmasıdır.

Türkiye'de pamuk üretiminde yaşanan azalışa ve tekstil sektörü başta olmak üzere hammadde kaynağı olduğu birçok sektörde yaşanan yatırım ve gelişmelere paralel olarak, pamuk tüketiminde ortaya çıkan artış iç üretim ile karşılanamadığından, Türkiye'nin pamuk ithalat miktarı yıllar itibariyle artmış ve net pamuk ihracatçısı olan Türkiye 1990'lı yıllarla birlikte pamuk ithal eden ülke pozisyonuna taşınmıştır (Tablo 3). 
Tablo 3: Türkiye Pamuk Dış Ticareti

\begin{tabular}{ccccc}
\hline \multicolumn{2}{c}{ ihracat } & \multicolumn{2}{c}{ ithalat } \\
\hline Yıl & $\begin{array}{c}\text { Miktar } \\
\text { (Milyon Ton) }\end{array}$ & $\begin{array}{c}\text { Değer } \\
\text { (Milyon Dolar) }\end{array}$ & $\begin{array}{c}\text { Miktar } \\
\text { (Milyon Ton) }\end{array}$ & $\begin{array}{c}\text { Değer } \\
\text { (Milyon Dolar) }\end{array}$ \\
\hline $2001 / 2002$ & 19 & 37,4 & 381 & 497 \\
$2005 / 2006$ & 15 & 66,4 & 762 & 960,8 \\
$2010 / 2011$ & 32 & 102,7 & 729 & $2.044,1$ \\
$2011 / 2012$ & 62 & 143,8 & 519 & $1.274,2$ \\
$2012 / 2013$ & 47 & 96,7 & 803 & $1.513,3$ \\
$2013 / 2014$ & 44 & 92,2 & 924 & $1.843,5$ \\
$2014 / 2015$ & 51 & 88 & 800 & 1.750 \\
$2015 / 2016$ & 48 & 76 & 786 & 1.233 \\
\hline
\end{tabular}

Kaynak: TÜiK, https://biruni.tuik.gov.tr/bitkiselapp/bitkisel.zul; TRADEMAP,

http://www.trademap.org/Product_SelCountry_TS.aspx

Tablo 3 incelendiğinde; pamuk ihracat rakamlarının çok ciddi değişikliğe uğramadığı; ithalatın ise dalgalı olarak artan bir seyir izlediği görülmektedir. 2011 yılında ihracatın 146 milyon dolar ile ithalatın ise 1.850 milyon dolar ile değer bazında zirve yapmıştır. Türkiye'nin 2015 yılı toplam 76 milyon dolarlık pamuk ihracatının yaklaşık \%20'si İtalya'ya, \%13'ü Polonya'ya ve \%8'i Hollanda'ya yapılırken; 1.232 milyon dolarlık ithalatının \%42,8'i ABD'den, \%17,4'ü Türkmenistan'dan ve \%14,6'sı Yunanistan'dan gerçekleştirilmektedir (Tablo 4).

Tablo 4: 2015 Yılı Türkiye Pamuk Ihracat ve Ithalatının Ülkelere Göre Dağılımı

\begin{tabular}{|c|c|c|c|c|c|c|}
\hline & \multicolumn{3}{|c|}{ İhracat } & \multicolumn{3}{|c|}{ İthalat } \\
\hline Sira & Ülkeler & $\begin{array}{c}\text { Ihracat } \\
\text { (Bin Dolar) }\end{array}$ & $\begin{array}{l}\text { Pay } \\
\text { (\%) }\end{array}$ & Ülkeler & $\begin{array}{c}\text { ihracat } \\
\text { (Bin Dolar) }\end{array}$ & $\begin{array}{l}\text { Pay } \\
\text { (\%) }\end{array}$ \\
\hline 1 & İtalya & 14.840 & 19,4 & $A B D$ & 527.652 & 42,8 \\
\hline 2 & Polonya & 10.091 & 13,2 & Türkmenistan & 215.478 & 17,4 \\
\hline 3 & Hollanda & 6.319 & 8,3 & Yunanistan & 180.749 & 14,6 \\
\hline 4 & Almanya & 4.786 & 6,3 & Brezilya & 113.857 & 9,2 \\
\hline 5 & $\begin{array}{l}\text { Rusya Fede- } \\
\text { rasyonu }\end{array}$ & 4.451 & 5,8 & Burkina Faso & 42.525 & 3,4 \\
\hline 6 & Yunanistan & 3.743 & 4,9 & Tacikistan & 33.625 & 2,7 \\
\hline 7 & $\begin{array}{l}\text { Mersin Ser- } \\
\text { best Bölge }\end{array}$ & 3.514 & 4,6 & Fildişi Kıyısı & 23.067 & 1,8 \\
\hline 8 & Bangladeş & 3.441 & 4,5 & Arjantin & 18.828 & 1,5 \\
\hline 9 & Bulgaristan & 3.058 & 4,0 & Hindistan & 13.542 & 1,1 \\
\hline \multirow[t]{3}{*}{10} & Fransa & 2.802 & 3,7 & Özbekistan & 11.033 & 0,9 \\
\hline & Diğer & 19.394 & 25,4 & Diğer & 52.096 & 4,2 \\
\hline & Toplam & 76.439 & 100 & Toplam & 1.232 .451 & 100 \\
\hline
\end{tabular}

Kaynak: Gümrük ve Ticaret Bakanlığı,

http://koop.gtb.gov.tr/data/56e95b3a1a79f5b210d9176f/2015\%20Pamuk\%20Raporu.pdf 


\section{Literatür}

Ulusal ve uluslararası yazın incelendiğinde; beyaz altın olarak nitelendirilen pamuğa gereken önemin verilmediği görülmektedir. Çok az çalışmaya konu edinilen pamuk, talep ve arz boyutu ile ayrı ayrı incelenmiş ve söz konusu çalışmalarda tek denklem, lojistik regresyon ve panel veri yöntemleri kullanılmıştır. Uluslararası yazında zaman serileri ve panel veri çalışmalarına yer verilirken, ulusal yazında çalışmalar zaman serileri ve lojistik regresyon ile gerçekleştirilmiştir.

Kalite bakımından hetorojen bir ürün olan pamuğu inceleyen ulusal ve uluslararası çalışmalar aşağıda sunulmuştur:

Wright (1971), Amerika ekonomisi için önemli bir yere sahip olan pamuk arzını pamuk fiyatlarının bir yıl gecikmeli değeri ile arsa satışlarının iki yıl gecikmeli değerlerinin bir fonksiyonu olarak tanımladığı çalışmasında; fiyatların gecikmeli değerleri ile pamuk arzı arasında anlamlı ve pozitif ilişki bulurken, arsa satışları ile pamuk arzı arasında bir ilişki bulamamıştır.

Coleman ve Thinpen (1991)'in dünya fiyatlarına entegre olan sekiz ülke üzerinde (her bir ülke ayrı ayrı) temellendirdiği çalışmalarında pamuk arzını dünya ve yerel fiyatları, ikame ürün fiyatları, girdi maliyeti (sulama ve gübre), zaman trendi ve üretim alanının bir fonksiyonu olarak oluşturmuşlardır. Dünya fiyatları ile arz fonksiyonu arasında sık sık istatistiki olarak anlamsız ilişki elde ederlerken yurt içi fiyatlar ile üretim düzeyi arasında anlamlı ve güçlü bir ilişki tespit etmişlerdir.

Beach vd. (2002)'nin 1975-2000 dönemlerine ait yıllık verilerin kullanıldığı çalışmalarında, ABD pamuk arzı; pamuk fiyatı, girdi fiyatları ve trendin bir fonksiyonudur. Çalışmada Klasik En Küçük Kareler (OLS) yöntemi kullanılmış olup, girdi fiyatlarının açıklayıcı değişken olarak dahil edilmediği modelde fiyat esnekliği 0,45 ; dahil edildiği modelde ise 0,49 olarak tespit edilmiştir.

Gillson vd. (2004), 1969-2001 dönem verilerini ve Bayesian Panel yöntemini kullanarak 26 üretici ülke verilerini kullanarak karşılaştırmalı bir analiz yapmışlardır. Çalışmada parametrelerin sıfır değerini almadığı varsayımı altında fark değerleri ile çalışılmıştır. Analiz sonucunda; dünya fiyatları ile pozitif ve pamuk üretim alanlarında üretimi gerçekleştirilebilecek ikame ürünlerin (mısır, pirinç, buğday ve soya fasulyesi) fiyatları ile negatif ilişki tespit edilmiştir.

Stepherd (2006)'ın Kalman filtresi kullanılarak oluşturduğu 30 ülke ve 16 FAOStat bölge için analiz ettiği kısa dönem pamuk arz fonksiyonunda; 1961-2004 dönemine ait veriler kullanılarak regresyon analizi yapılmış olup, ülkeler hatta bölgeler arasında ürünün hetorojenlik gösterdiği, bu nedenle dünya fiyatlarında yaşanan değişimin her bölge için farklı sonuçlar doğurduğu sonucu elde edilmiştir.

Aktaş (2006)'ın 1980-2002 dönem verilerini kullandığı çalışmasında, Çukurova Bölgesine ait pamuk arz fonksiyonu oluşturmuş ve üretici fiyatları, ikame malların fiyatları (buğday, mısır) ve sübvansiyon değişkenleri arasındaki ilişki OLS tahmin yöntemi ile analiz edilmiştir. Analiz sonucunda, tahmin edilen pamuk arz modelinde, pamuğun esnekliği 0,56, mısırın kısa dönem çapraz fiyat esnekliği ise $-0,49$ olarak tespit edilmiştir.

Kotakou (2011), Yunanistan'a ait 1991-2002 dönem verilerini kullandığı çalışmasında; pamuk arzı fiyat esnekliği ile çiftlik büyüklükleri arasındaki ilişkiyi çiftlikleri üç kategoriye (küçük, orta ve büyük) ayırarak dengesiz panel veri yöntemi ile incelemiş ve analiz sonucunda çiftlik büyüklükleri arttıkça pamuk arzı fiyat esnekliklerinin düştüğü sonucunu elde etmiştir.

Özüdoğru ve Miran (2015), Gıda Tarım ve Hayvancılık Bakanlığı Çiftçi Kayıt Sisteminden (ÇKS) elde ettikleri 2012 dönem verilerini kullanarak; Şanlıurfa, Aydın, Adana, Hatay ve Diyar- 
bakır illerine ait pamuk arz fonksiyonunu Tobit model kullanarak tahmin etmişlerdir. Yapılan analiz sonuçlarına göre, üreticilerin ikame ürün fiyatlarını takip ettikleri, pamuk fiyatındaki artışa pozitif tepki ve ikame ürün fiyatlarındaki artışa karşı ise negatif tepki verdikleri sonucuna ulaşmışlardır.

Karaman vd. (2015), 1960-2010 dönemine ait yıllık verilerin kullanıldığı çalışmalarında, Dinamik Vektör Otoregressif (VAR) modeli yardımı ile Türkiye kütlü pamuk fiyatının belirlenmesinde, arz ve talep faktörlerinin etkisi, yurtiçi stok kullanım oranı ve rekabetçi iki ülkenin stok kullanım oranı (ABD ve Yunanistan), destekleme politikası ve kriz kukla değişkenleri kullanımıştır. Yapılan analiz sonucunda; devlet destekleme politikasında ortaya çıkan değişikliklerin pamuk fiyatları üzerinde önemli bir etkiye sahip olmadığı, 1973 petrol krizinin pamuk fiyatlarında yapısal değişime neden olduğu, iki rekabetçi ülkenin stok kullanım oranı ve yurtiçi stok kullanım oranı arasında ileriye doğru tek yönlü nedensellik ilişkisinin var olduğu ve iki rekabetçi ülkenin stok kullanım oranından yurtiçi stok kullanım oranına doğru ise tek yönlü bir nedensellik ilişkisinin var olduğu sonucunu elde edilmiştir.

\section{Ekonometrik Tahmin ve Sonuçları}

\subsection{Veri Seti ve Model}

Bölgesel bazda pamuk arz fonksiyonunun incelendiği bu çalışmada aşağıda yer alan arz fonksiyonundan yararlanılarak analiz gerçekleştirilmiştir.

$$
Q_{i, t}=P_{i, t}+P D_{i, t}+S T_{t}+u_{i, t}
$$

Eşitlik 1'de yer alan pamuk arz fonksiyonu; Ege, Akdeniz, Güneydoğu Anadolu ve Marmara Bölgesine ait pamuk üretim miktarı $(Q)$, dört bölge için cari döneme ait pamuk fiyatları $(P)$, alternatif ürünlerin (mısır, soya ve buğday) fiyatları $(P D)$ ve bir önceki döneme ait pamuk stoku $(S T)$ değişkenlerinden oluşmaktadır. Çalışmanın bölge bazlı yapılması nedeniyle bölgelere ait maliyet değerlerinin son yıllarda hesaplanmaya başlanması ve serinin geriye doğru yürütülememesi, dünya fiyatlarının değişken olarak alındığı modelde istatistiki ve iktisadi olarak anlamsız sonuçlar elde edilmesi nedenleri ile ilgili değişkenler modele dahil edilmemiştir. Analiz edilen bölgeler için pamuk üretiminin ikamesi olan mısır, buğday ve soya ürünleri ise panel veri yönteminin getirdiği değişken girdi sayısı kısıtı nedeniyle ağırlıklı ortalama değerleri alınarak modele dahil edilmiştir.

Analiz edilen bölgelere ait 2000-2015 dönemlerini kapsayan veriler, Türkiye İstatistik Kurumu (TÜIK), İzmir Ticaret Odası (ITO), Tarım, Gıda ve Hayvancılık Bakanlığı ve Uluslararası Pamuk Danışma Komitesi (ICAC) web sayfalarından yazar tarafından derlenmiştir. Birden fazla bölgeye ait zaman serisi ile çalışıldığı için analiz yöntemi olarak yatay kesit ve zaman serilerini birleştiren panel veri yöntemi kullanılmıştır. Analizin yapılmasında Eviews 9, Stata 14.1 ve Gauss paket programlarından yararlanılmıştır.

Son zamanlarda yapılan ve ekonometrik analiz içeren iktisadi çalışmaların çoğunda yer verilen panel veri analizinin kullanımı giderek yaygınlaşmaktadır. Özellikle tahmin yöntemlerinin ve teorik altyapısının hızlı gelişimi; panel veri analizinin, ekonometri literatürünün en aktif ve yenilikçi parçası haline gelmesinin nedenlerinden birisidir (Greene, 2003: 284). Ayrıca, panel veri iki boyutlu bir veri türü olduğundan içerisinde birçok avantaj barındırmaktadır. Yapısı itibariyle hem zaman hem de yatay kesit verilerini bir araya getiren panel veri analizi daha fazla veriyle çalışmayı ve daha yüksek serbestlik derecesi ile tahminler yapmayı mümkün kıl- 
maktadır. Gözlem sayısında yaşanan bu artış ise çoklu doğrusal bağıntı sorununu ortadan kaldırmaktadır (Hsiao, 2002: 1). Ayrıca panel veri yönteminin yatay kesitlere özgü heterojenliği dikkate alması, model spesifikasyon hatası nedeniyle ortaya çıkan sorunlara çözüm getiren yöntemler içermesi, çoklu doğrusal bağlantı sorununu azaltması ve kapsamlı davranışsal modelleri test edebilmesi; panel verinin getirdiği avantajlardan en önemlileridir (Baltagi, 2005: 59). Panel veri regresyon modeli aşağıdaki denklem kullanılarak analiz edilmektedir (Baltagi, 2011:305):

$$
y_{\text {it }}=\alpha+X_{\text {it }}^{t}+u_{\text {it }}
$$

Eşitlik $2^{\prime} \mathrm{de}^{i(i=1,2, \ldots, N)}$ kesiti $^{t}$ ise $(t=1,2, \ldots, T)$ ile zaman periyodunu ifade etmektedir. ${ }^{u_{i t}}$ hata teriminin tüm zaman ve birimler için bağımsız olduğu ve $u_{i t} \approx I I D\left(0, \sigma^{2}\right)$ dağılım gösterdiği varsayılmaktadır.

Panel veri modeli, Havuzlanmış En Küçük Kareler (HEKK - Pooled OLS, Klasik Model), Sabit Etkiler (Fixed Effects) ve Rassal Etkiler (Random Effects) yaklaşımlarından biri kullanılarak tahmin edilmektedir. Birim ve zaman etkilerinin homojen olduğu durumda, hata terimi her iki etkiyi de içermediği durumda, etkin ve tutarlı tahminciler veren HEKK Yöntemi, eğim parametrelerinin tüm yatay kesit birimler için aynı, sabit parametrenin birimler arasında farklılaştığı (birim etki içerdiği) durumda Sabit Etkiler (SE) yaklaşımı ve eğim parametreleri yatay kesitler arasında değişiyorsa ve örnekteki birimler rassal olarak seçildiği durumda ise Rassal Etkiler (RE) yaklaşımı kullanılmaktadır. Panel veri modellerinden hangisinin uygun olduğuna karar verebilmek için F, Olabilirlik Oranı, Breusch-Pagan LM, Score, Woldridge ve Hausman testleri kullanılmaktadır (Çatalbaş ve Yarar, 2015: 107; Tatoğlu, 2013: 164-184). Çalışmada Hausman testinden yararlanılacaktır.

Yatay kesit ve zaman serilerin birlikte kullanılmasından kaynaklı olarak panel veri analizlerinde birkaç problem ortaya çıkabilmektedir. Bu nedenle panel veri analizinde de yatay kesit serilerde karşılaşılan yatay kesit bağımlılığı ve zaman serilerinde karşılaşılan birim kökün varlığı problemlerine dikkat edilmelidir (Bilman, 2014: 167). Panel veri analizi serilerinin durağanlığı aşağıdaki denklem yardımı ile analiz edilmektedir.

$$
\Delta y_{i t}=\alpha y_{i t-1}+\sum_{j=1}^{p i} \beta_{i j} \Delta y_{i t-1}+x_{i t}^{s} \delta+\varepsilon_{i t}
$$

Panel regresyon analizi sonucu elde edilen tahminlerin yansız ve tutarlı olması için hem zaman serileri birim kök içermemesi hem de birimler arasında yatay kesit bağımlılığının olmaması gerekmektedir. Son dönemde geliştirilen panel birim kök testleri bu gerekliliği göz önünde bulundurarak; birim kök analizinden önce panel verinin yatay kesit tarafından kaynaklanan yatay kesit bağımlılığının araştırılmasını önermektedir (Baltagi ve Pesaran, 2007: 229). Yatay kesit bağımlıı̆̆ının varlığını test etmek amacıyla literatürde Breusch-Pagan LM (1980), Pesaran (2004), Friedman (1937) ve Frees $(1995,2004)$ testleri kullanılmaktadır (Tatoğlu, 2013: 215-220).

Panel veri modelleri; hata teriminin birimler arasında korelasyon (yatay kesit bağımlılığı) barındırmadığı varsayımının yanında birim içinde ve birimler arasında eşit varyanslı olduğu (homoskedasite) ve birim içinde korelasyon (otokorelasyon) barındırmadığı varsayımlarına da dayanmaktadır. Modelde temel varsayımların hepsi sağlanıyorsa, kullanılan panel veri yakla- 
şımına uygun olan tahmin yöntemlerinden biri tercih edilebilmektedir (Hsiao, 2002: 55-59; Baltagi, 2013: 91-96).

\subsection{Araştırma Bulguları}

Bölgesel pamuk arzının incelendiği bu çalışmada, Hausman testi yardımı ile iki yönlü sabit etkiler modelinin geçerli olduğu saptanmıştır (EK-1.a,b). Zaman serilerine uygulanacak birim kök testine karar vermeden önce Pesaran CD testi ile panel veride yatay kesitler arasında korelâsyonun (yatay kesit bağımlılı̆ı) varlığı incelenmiş ve test sonucu elde edilen olasılık değerlerine $(0,0000)$ göre yatay kesit bağımlılığının varlığına karar verilmiştir (Ek-2). Yatay kesit bağımlıığının varlığı tespit edilen seri için birim kökün varlığı birinci kuşak birim kök testleri ile analiz edilmiş ve elde edilen sonuçlar aşağıdaki tabloda sunulmuştur (Tablo 5).

Tablo 5: Panel Birik Kök Testi Sonuçları (Düzey ve 1.Farklarda)

\begin{tabular}{|c|c|c|c|c|}
\hline \multirow[t]{2}{*}{$Q$} & \multicolumn{2}{|c|}{$\mathrm{I}(0)$} & \multicolumn{2}{|c|}{$\mathrm{I}(\mathrm{I})$} \\
\hline & İstatistik & Olasılık (p) & İstatistik & Olasılık (p) \\
\hline Levin, Lin \& Chu t & $-1,0243$ & 0,1529 & $-7,0706$ & 0,0000 \\
\hline Im, Pesaran and Shin & $-0,7401$ & 0,2296 & $-4,9964$ & 0,0000 \\
\hline ADF - Fisher Chi-square & 10,5839 & 0,2264 & 36,5441 & 0,0000 \\
\hline PP - Fisher Chi-square & 9,5153 & 0,3007 & 50,2268 & 0,0000 \\
\hline \multirow[t]{3}{*}{$P$} & $I(0)$ & & $\mathrm{I}(\mathrm{I})$ & \\
\hline & İstatistik & Olasılık (p) & İstatistik & Olasılık (p) \\
\hline & $-3,0278$ & 0,0012 & $-8,3997$ & 0,0000 \\
\hline Im, Pesaran and Shin & $-1,4706$ & 0,0707 & $-6,7444$ & 0,0000 \\
\hline ADF - Fisher Chi-square & 12,9644 & 0,1131 & 48,5395 & 0,0000 \\
\hline PP - Fisher Chi-square & 12,7880 & 0,1194 & 72,0572 & 0,0000 \\
\hline \multirow[t]{3}{*}{ ST } & $\mathrm{I}(0)$ & & $\mathrm{I}(\mathrm{I})$ & \\
\hline & İstatistik & Olasılık (p) & İstatistik & Olasılık (p) \\
\hline & $-1,4197$ & 0,0779 & $-4,0054$ & 0,0000 \\
\hline Im, Pesaran and Shin & 0,1644 & 0,5652 & $-2,0704$ & 0,0192 \\
\hline ADF - Fisher Chi-square & 4,9708 & 0,7607 & 16,2402 & 0,0391 \\
\hline PP - Fisher Chi-square & 4,9708 & 0,7607 & 16,4680 & 0,0362 \\
\hline \multirow[t]{2}{*}{ PD } & $\mathrm{I}(0)$ & & $\mathrm{I}(\mathrm{I})$ & \\
\hline & İstatistik & Olasılık (p) & İstatistik & Olasılık (p) \\
\hline Levin, Lin \& Chu t & $-1,9382$ & 0,0263 & $-6,8922$ & 0,0000 \\
\hline Im, Pesaran and Shin & $-0,4994$ & 0,3087 & $-5,2645$ & 0,0000 \\
\hline ADF - Fisher Chi-square & 7,6016 & 0,4733 & 37,9275 & 0,0000 \\
\hline PP - Fisher Chi-square & 7,5526 & 0,4733 & 38,3822 & 0,0000 \\
\hline
\end{tabular}

Tablo 6'da yer alan panel birim kök testi sonuçları incelendiğinde; yatay kesit birimlerine ait $Q, P, P D$ ve ST değişkenlerinin düzey değerlerinde durağan olmadıkları, birinci sıra fark değerlerinde durağan oldukları görülmektedir. Serilerin fark değerleri ile yapılacak analizle sahte regresyon sorunu ile karşılaşılamayacağı görülmektedir. Ayrıca yatay kesit bağımlılığının varlığı belirlenen seriler için daha güvenilir ve tutarlı sonuçlara ulaşabilmek için yatay kesit bağımlılığını dikkate alan ikinci nesil birim kök testlerinden Breuer, McNown ve Wallace (1999) 
tarafından geliştirilen ve yatay kesit bağımlılığının olduğu durumlarda paneli oluşturan her bir kesit için birim kökün incelenebildiği SURADF (Seemingly Unrelated Regression Augmented Dickey-Fuller Test) Testi uygulanmıştır² (Tablo 6) (Öksüzkaya, 2013: 34).

Tablo 6: SURADF Testi Sonuçları (Sabit)

\begin{tabular}{|c|c|c|c|c|}
\hline & SUR ADF & 0,01 & 0,05 & 0,10 \\
\hline \multicolumn{5}{|l|}{ Q } \\
\hline Ege Bölgesi & $-1,720$ & $-3,959$ & $-3,081$ & $-2,681$ \\
\hline Akdeniz Bölgesi & $-2,731^{* * *}$ & $-4,004$ & $-3,098$ & $-2,690$ \\
\hline Marmara Bölgesi & $-0,839$ & $-3,959$ & $-3,081$ & $-2,681$ \\
\hline Güneydoğu Anadolu & $-2,118$ & $-3,959$ & $-3,081$ & $-2,681$ \\
\hline \multicolumn{5}{|l|}{$P$} \\
\hline Ege Bölgesi & $-2,183$ & $-3,959$ & $-3,081$ & $-2,681$ \\
\hline Akdeniz Bölgesi & $-1,495$ & $-4,004$ & $-3,098$ & $-2,690$ \\
\hline Marmara Bölgesi & $-1,786$ & $-3,959$ & $-3,081$ & $-2,681$ \\
\hline Güneydoğu Anadolu & $-1,922$ & $-3,959$ & $-3,081$ & $-2,681$ \\
\hline \multicolumn{5}{|l|}{ PD } \\
\hline Ege Bölgesi & $-1,117$ & $-4,728$ & $-3,759$ & $-3,324$ \\
\hline Akdeniz Bölgesi & $-1,786$ & $-3,959$ & $-3,081$ & $-2,681$ \\
\hline Marmara Bölgesi & $-1,117$ & $-4,728$ & $-3,759$ & $-3,324$ \\
\hline Güneydoğu Anadolu & $-1,701$ & $-3,959$ & $-3,081$ & $-2,681$ \\
\hline \multicolumn{5}{|l|}{ ST } \\
\hline & $-0,538$ & $-4,004$ & $-3,098$ & $-2,690$ \\
\hline
\end{tabular}

I) Maksimum gecikme uzunluğu olarak 4 alınmıştır ve optimal gecikme uzunluğu CADF Birim Kök testi yardımıyla elde edilmiştir.

II) Kritik değerler, 1000 bootstrap dağııımından elde edilmiştir.

$*, * *, * * *$ işaretleri değişkenlerin sırası ile $\% 1, \% 5$ ve $\% 10$ anlamlılık düzeylerinde anlamlı olduğunu ifade etmektedir.

Her bir bölge için denklemin katsayılarının farklılaşmasına imkan tanıyan SURADF Testi sonuçları incelendiğinde; yatay kesit birimlerine ait Monte Carlo Simülasyonu sonucu ulaşılan kritik değerler ile SURADF test istatistikleri karşılaştırıldığında, paneli oluşturan kesitlerin durağan olmadığına karar verilmiştir.

Birinci ve ikinci nesil birim kök içeren seriler arasında eşbütünleşme ilişkisinin varlığı, Pedroni eşbütünleşme testi ile analiz edilmiş ve elde edilen sonuçlar Tablo 7'de sunulmuştur.

\footnotetext{
${ }^{2}$ SURADF testinde kullanılacak olan, birimlere ait uygun optimum gecikme uzunluklarının belirlenmesi için öncelikle CADF Birim Kök Testi (Pesaran, 2006) yapılmıştır.
} 
Tablo 7: Panel Eşbütünleşme Testi Sonuçları

\begin{tabular}{|c|c|c|c|c|}
\hline \multicolumn{5}{|c|}{ Pedroni Eşbütünleşme Testi } \\
\hline & Test İstatistiği & Olasılık (p) & Test İstatistiği & Olasılık (p) \\
\hline Panel v-ístatistiği & $-0,250027$ & 0,5987 & $-0,176$ & 0,5698 \\
\hline Panel rho-İstatistiği & 0,562105 & 0,713 & 0,70053 & 0,7582 \\
\hline Panel PP-i̇statistiği & $-2,657354$ & 0,0039 & $-1,8943$ & 0,0291 \\
\hline Panel ADF-İstatistiği & $-2,498263$ & 0,0062 & $-2,0356$ & 0,0209 \\
\hline Group rho-İstatistiği & 1,49369 & 0,9324 & -- & -- \\
\hline Group PP-İstatistiği & $-2,557331$ & 0,0053 & -- & -- \\
\hline Group ADF-İstatistiği & $-2,172724$ & 0,0149 & -- & -- \\
\hline
\end{tabular}

Tablo 7 incelendiğinde; Pedroni Testi sonuçlarına göre 11 adet eşbütünleşme ilişkisini gösteren istatistikten 6 adeti anlamlı bulunmuş ve seriler arasında eşbütünleşme ilişkisinin varlığını kabul eden alternatif hipotezi kabul edilmiştir. Pedroni Testi sonuçlarına göre eşbütünleşme olduğu sonucuna ulaşılmış ve Ege, Akdeniz, Marmara ve Güney Doğu Anadolu bölgeleri pamuk arzı ile pamuk fiyatı, ikame (buğday, mısır, soya) ürün fiyatları ve pamuk stok değerinin uzun dönemde birlikte hareket ettiklerine karar verilmiştir.

Eşbütünleşik serilerin yer aldığı modelin analizine geçmeden önce; sabit etkiler yaklaşımına göre kurulan pamuk arzı modelinin temel varsayımları ${ }^{3}$ sağlayıp sağlamadığı kontrol edilmiştir. Yatay kesit bağımlılı̆̆ tespit edilen panel verinin değişen varyans varsayımını sağlayıp sağlamadığı, Değiştirilmiş Wald testi, otokorelasyon varsayımı ise Bhargava, Franzini ve Narendranathan'ın DW Testi yardımıyla kontrol edilmiştir. Değiştirilmiş Wald testi olasılık değeri $(0,1808)$ dikkate alındığında sıfır hipotezi \%1 anlamlııı düzeyinde kabul edilmiş ve modelin sabit varyans varsayımı sağladığı görülmüştür. Otokorelasyon sorunu ise DW testi ile incelenmiş ve test istatistiki 0,922 bulunmuştur. Test istatistik sonucuna göre birinci mertebeden otokorelasyonun var olduğuna karar verilmiştir. Otokorelasyon sorunundan kurtulmak için $A R(1)$ süreci işletilmiş ve elde edilen panel tahmin sonuçları aşağıda sunulmuştur.

Tablo 8: Panel Veri Analizi Sabit Etkili Modelin Tahmin Sonuçları

\begin{tabular}{lcccc}
\hline & Katsayı & Standart Hata & t istatistik & Olasılık \\
\hline P & 0,4256 & 0,2266 & 1,8774 & 0,0661 \\
PD & $-0,4124$ & 0,1585 & $-2,6010$ & 0,0121 \\
ST & $-0,0078$ & 0,0044 & $-1,7540$ & 0,0853 \\
AR(1) & 0,6495 & 0,0967 & 6,7154 & 0,0000 \\
Sabit & 0,7424 & 0,2325 & 3,1929 & 0,0024 \\
\hline R2 & 0,9852 & F-ístatistik & \multicolumn{2}{c}{494,7047} \\
\hline D-W ist. & 1,9972 & F-istatistik Olasılık & \multicolumn{2}{c}{0,0000} \\
\hline
\end{tabular}

\footnotetext{
${ }^{3}$ Panel veri modellerinde; (i) hata teriminin birim içerisinde ve birimlere göre homoskedastik (eşit varyanslı), (ii) yatay kesitler ile hata terimleri arasında ilişki (yatay kesit bağımlıık) yok ve (iii) hata terimleri arasında ilişki yok temel varsayımları yapılmaktadır (Tatoğlu, 2013: 197).
} 
Tablo 8'de yer alan F test istatistiği ve olasılık değerleri; modelin genel olarak anlamlı; $R^{2}$ değeri ise bağımsız değişkenlerin bağımlı değişkeni açıklama gücünün yüksek ve \%98 olduğunu göstermektedir. Bağımsız değişkenlere ait t-istatistikleri ve olasılık değerleri incelendiğinde ise her birinin \%10 anlamlılık düzeyinde anlamlı olduğu görülmektedir. İstatistiki açıdan anlamlı olan modelin iktisadi açıdan da işaretlerinin beklentilerle uyumlu olduğu görülmektedir. Model sonuçlarına göre pamuk fiyatları, diğer malların fiyatları ve pamuk stokunun pamuk arzı üzerinde anlamlı bir etkiye sahip olduğu görülmektedir. Bölgesel pamuk arzının bağımsız değişkenlerdeki değişimlere verdiği tepki; pamuk fiyatında ortaya çıkan \%1'lik bir artışın pamuk arzında \%42 oranında bir artışa sebep olurken; diğer malların fiyatında ortaya çıkan \%1'lik bir artışın pamuk arzı üzerinde \%41 oranında bir azalışa sebep olmaktadır. Çapraz fiyat esnekliğinin işareti, mısır, soya ve buğday'ın pamuğun yakın ikamesi olduğunu ifade etmektedir. Pamuk stok değeri de diğer malların fiyatları gibi pamuk arzı üzerinde negatif bir etkiye sahiptir ve bu etki \%0.08 oranında gerçekleşmektedir.

\section{Sonuç, Tartışma ve Öneriler}

Bu çalışmada, bölgeden bölgeye farklı kalitede üretilen yani hetorojen ürün diyebileceğimiz pamuğun arzını etkileyen faktörler; Ege, Marmara, Akdeniz ve Güney Doğu Anadolu Bölgesi çatısı altında 2000-2015 yıllarına ait veriler kullanılarak panel veri yöntemi ile analiz edilmiştir. İlk olarak modelde kullanılacak panel veri yöntemi sırası ile Hausman ve Wald testleri kullanılarak analiz edilmiş ve sabit etkiler modelinin kullanılmasına karar verilmiştir. Sabit etkiler modelinin kullanılacağı çalışmada sahte regresyon sorununu ortadan kaldırmak için değişkenlerin tamamına birinci kuşak ve ikinci kuşak birim kök testleri uygulanmış ve yapılan analiz sonucunda bütün değişkenlerin birinci sıra fark durağan olduklarına karar verilmiştir. Modelde kullanılacak değişkenlerin birim kök testlerinin ardından serilere eşbütünleşme testleri uygulanmış; Pedroni ve Johansen Fisher Eşbütünleşme Testleri sonuçlarına göre seriler arasında eşbütünleşmenin varlığı sonucuna ulaşılırken, Kao Eşbütünleşme Testi sonucuna göre ise değişkenler arasında eşbütünleşmenin var olmadığı sonucuna ulaşılmıştır. Eşbütünleşme teslerinin çoğunluğu eşbütünleşme olduğunu destekler sonuçlar verdiği için uzun dönemde pamuk arzı ile pamuk fiyatları, diğer malların fiyatları ve pamuk stok değeri arasında ilişki olduğu kabul edilmiştir. Son olarak sabit etkiler modeli kullanılarak değişkenlere ait panel veri analizi yapılmıştır. Analiz sonucunda; pamuk arzının fiyat ve çapraz fiyat esnekliği literatürdeki diğer çalışmalar (Wright, 1971; Coleman ve Thinpen, 1991; Beach vd., 2002; Aktaş, 2006) ile uyumlu olduğu görülmüştür. İstatistiki ve iktisadi olarak anlamlı olan regresyon analizi sonuçlarına göre, pamuk fiyatlarında yaşanan \%1'lik bir artış pamuk arzında \%42'lik bir artışa; bölgesel pamuk stokunda ve ikame malların fiyatında yaşanan \%1'lik bir artış ise pamuk arzında sırasıyla \%0,08 ve \%41'lik bir azalışa neden olmaktadır. Arz esneklik katsayısının sıfır ile bir arasında bir değer aldığı ve pamuğun esnek olmayan arz özelliği taşıdığı görülmektedir. Bunun altında yatan nedenin pamuk üretiminde Türkiye'nin verimliliği yüksek olmasına rağmen girdi fiyatlarının yüksel gerçekleşmesi ve ürüne uygulanan teşvik politikalarının rakip ülkelerle rekabet edecek imkânı tanımaması ve Çin gibi pamuk üretiminde önemli bir yere sahip olan ülkelerin uyguladığı pamuk stok politikalarının bir sonucu olarak yurt içi fiyatların düşük seyretmesi sayılabilmektedir. Ayrıca son yıllarda özellikle Ege ve Çukurova gibi pamuk üretimine elverişli alanlarda yaşanan maliyet artışları ve ikame malların (buğday, mısır ve soya) fiyatlarında ortaya çıkan olumlu gelişmelerin bir sonucu olarak pamuk üretimde daralma yaşanmıştır. Pamuk arzında ortaya çıkan bu daralma pamuğun birçok sektörün temel girdisi olması sebebi ile çok ciddi oranlarda gerçekleşmemiştir. Pamuk arz esneklik katsayısı sıfır ile bir değe- 
ri arasında yer alması bu durumu destekler niteliktedir. Çin'in kontrolünde gelişen dünya pamuk stoku, devam eden süreç için de de pamuk sektörünü en çok etkileyen konulardan biri olmaya devam edecektir. Uzun yıllardır artış eğilimi içinde olan pamuk stoku, 2008 yılında yaşanan küresel ekonomik krizin ardından hızlı bir artış trendine girmiş ve art arda arz fazlası yaşanmıştır. Arz fazlasına bağı olarak pamuk stoku yıllar içinde artış göstermiştir. Ayrıca pamuğun stoklanabilme özelliği de pamuk arz esnekliğini etkilemekte ve artırmaktadır.

Sonuç olarak pamuğun Türkiye ekonomisindeki stratejik önemi dikkate alındığında; pamuk üretimi, tüketime cevap verebilecek seviyelere getirilmesi amaçlanmalı ve buna uygun politikalar geliştirilmelidir. Özellikle yüksek verim ve kalitede üretim yapan bölgeler için maliyet sorunu çözülerek ve sübvanse edici politikalarla desteklenerek pamuk fiyatı dünya fiyatları ile rekabet edebilecek seviyelere taşınmalıdır. 2011 yılından itibaren uygulanan havza bazlı destekleme modelinin etkinlik derecesi artırılarak verimli bölgelerin üretimi desteklenmelidir. Pamuk üretiminin yurt içi tüketimi karşılayacak seviyeye gelene kadar, ithalatın daha düşük bedellerle gerçekleştirilebilmesi için alternatif pazarlardan pamuk ithalatı gerçekleştirilmelidir. 


\section{Kaynaklar}

AKTAŞ, E. (2006), “Çukurova Bölgesi'nde Pamuk Arzı Duyarlılığının Tahmini Üzerine Bir Çalışma”, Tarım Ekonomisi Dergisi, 12(1):3-8.

BALTAGI, B. H. (2005), Econometric Analysis of Panel Data (2. Edition), John Wiley \& Sons Ltd., New York. (2011), Econometrics, Fifth Edition, Springer, New York (2013). Econometric Analysis of Panel Data (5. Edition). John Wiley and Sons Ltd., London.

BALTAGI, B. H. ve PESARAN, M. H. (2007), "Heterogeneity and Cross Section Dependence in Panel Data Models: Theory And Applications", Journal of Applied Econometrics, 22(2), 229-232.

BEACH, R. H., B. C. MURRAY, N. E. PIGGOTT, ve M. K. WOHLGENANT (2002), "Interaction Effects of Promotion, Research, and Price Support Programs for US Cotton," The American Agricultural Economics Association Annual Meetings, Long Beach, CA, July 28-31, 1-29.

BREUSCH, T.S ve A.R., PAGAN (1980), "The Lagrange Multiplier Test and Its Aplicitiations to Model Specification In Econometrics", Review of Economic Studies, Blackwell Publishing, 47(1), 239-253.

BREUER, J.B., R. MCNOWN ve M.S. WALLACE (1999), "Series-specific Tests for Unit Root in a Panel Setting with an Application to Real Exchange Rates." Discuscussion Paper No. 99-9, University f Colorado, June 1999.

BILMAN, A. S. (2014), Ticari Açıklık Büyüme Etkileşimi: Panel Veri Analizi ve Ülkelerarası Karşılaştırma (Interaction between Trade Openness and Growth: Panel Data Analysis and Comparison between Countries), Doctoral Thesis, Dokuz Eylül University, Department of Economics, İzmir.

COLEMAN, J. ve M. E. THIGPEN (1991), "An Econometric Model of the World Cotton and Non-Cellulosic Fibres Markets," World Bank Staff Commodity Working Paper No. 24.

ÇATALBAŞ, G., K. ve Ö. YARAR (2015), "Türkiye'deki Bölgeler Arası İç Göçü Etkileyen Faktörlerin Panel Veri Analizi ile Belirlenmesi (Determination of Factors Affecting Internal Migration in Turkey with Panel Data Analysis)", Alphanumeric Journal, 3(1), 99-117.

FREES, E. W. (1994), Assessing Cross-Sectional Correlation in Panel Data, School of Business, University of Wisconsin, Madison. WI 53 706, USA.

FRIEDMAN, M. (1937), The Use qf Ranks to Avoid the Assumption of Normality Implicit in the Analysis of Variance." Journal of the American Statistical Association, 32(200): 675-701.

GILLSON, I., C. POULTON, K. BALCOMBE ve S. PAGE (2004), "Understanding the Impact of Cotton Subsidies on Developing Countries", Working Paper, www.odi.org.uk. (Erişim:11.08.2016)

GREENE, W. H. (2003), Econometric Analysis (5. Edition), Prentice Hall, New Jersey.

GÜMRÜK VE TICARET BAKANLIĞI, (2012), 2012 Yılı Pamuk Raporu, Kooperatifçilik Genel Müdürlüğü, http://koop.gtb.gov.tr/data/53319a8c487c8eb1e43d728b/2012\%20Y\%C4\%B1l\%C4\%B1\%20Pamuk\%20Raporu.pd f, (Erişim: 13.08.2016).

(2014), 2014 Yılı Pamuk Raporu, Kooperatifçilik Genel Müdürlüğü, http://koop.gtb.gov.tr/data/53319e1b487c8eb1e43d729d/2014\%20Pamuk\%20Raporu.pdf, (Erişim: 13.08.2016).

(2015), 2015 Yılı Pamuk Raporu, Kooperatifçilik Genel Müdürlüğü, http://koop.gtb.gov.tr/data/56e95b3a1a79f5b210d9176f/2015\%20Pamuk\%20Raporu.pdf, (Erişim: 13.08.2016).

HSIAO, C., (2002), Analysis of Panel Data (2. Edition), Cambridge University Press, New York.

ICAC (Uluslararası Pamuk Danışma Kurulu), (2016), https://icac.generation10.net/statistics/index, (Erişim: 13.08.2016).

ITO (İstanbul Ticaret Odası), (2003), Pamuk Sektör Profil Araştırması, http://www.ito.org.tr/Dokuman/Sektor/172.pdf, (Erişim: 13.08.2016).

KARAMAN, S., A. KOÇAK ve G. TEZEL (2015), "Determinants of Cotton Prices in Turkey: A VAR Approach", Tarım Ekonomisi Araştırmaları Dergisi, 1(2):1-8.

KOTAKOU, C. (2011), "Panel Data Estimation Methods on Supply and Demand Elasticities: The Case of Cotton in Greece", Journal of Agricultural and Applied Economics, 43(1), 111-129.

ÖKSÜZKAYA, M. (2013), Seçilmiş AB Ülkeleri İçin Gelir-Tüketim İlişkisi: Panel Veri Yaklaşımı. Yayımlanmamış Yüksek Lisans Tezi, T.C. Çukurova Üniversitesi, Ekonometri Anabili Dalı, Adana.

ÖZÜDOĞRU, T. ve B. MiRAN (2015), "Türkiye'de Farklı Destekleme Politikalarının Pamuk Arzı Üzerine Etkileri”, Tarım Ekonomisi Araştırmaları Dergisi, 1(2): 9-19. 
PESARAN, M. H. (2004), “General Diagnostic Tests for Cross Section Dependence in Panels," University of Cambridge, Faculty of Economics, Cambridge Working Papers in Economics No. 0435.

STEPHERD (2006), Estimating Price Elasticities of Supply for Cotton: A Structural Time-Series Approach, FAO Commodity and Trade Policy Research Working Paper No. 21

TATOĞLU, F. Y. (2013), Panel Veri Ekonometrisi Stata Uygulamalı (Econometric Analysis of Panel Data) (2. Edition), Beta Yayıncılık, İstanbul.

TÜiK, Bitkisel Üretim İstatistikleri, https://biruni.tuik.gov.tr/bitkiselapp/bitkisel.zul, (Erişim: 13.08.2016).

TRADEMAP, http://www.trademap.org/Product_SelCountry_TS.aspx, (Erişim: 15.10.2016)

TZOB (Türkiye Ziraat Odaları Birliği), (2004), Pamuk Çalışma Grubu Raporu http://www.tzob.org.tr/Portals/0/Dokumanlar/FaaliyetRaporlari/docs/pamuk.pdf, (Erişim: 21.09.2016).

WRIGHT, G. (1971), “An Econometric Study of Cotton Production and Trade, 1980-1860", The Review of Economics and Statistics, LIII(2): 111-120.

\section{Ek-1}

\section{1.a. Hausman Testi Sonucu}

\begin{tabular}{lllll}
\hline $\begin{array}{l}\text { Illişkili Rassal Etki - Hausman Testi } \\
\text { Yatay Kesit Rassal Etki Testi }\end{array}$ & & & \\
\hline Test Özeti & & $\begin{array}{l}\text { Chi-Sq. } \\
\text { Istatistiği }\end{array}$ & $\begin{array}{l}\text { Chi-Sq. Serb. } \\
\text { Derecesi }\end{array}$ & Olasılık \\
\hline Yatay Kesit Rassal & & & 3 & 0,0000 \\
\hline Yatay Kesit Rassal & Sabit & Rassal & Varyans & Olasılık \\
\hline Değişken & $1 \mathrm{E}+06$ & $-1 \mathrm{E}+06$ & 0,000683 & 0,0000 \\
\hline P & 0,687823 & 0,738477 & 0,000048 & 0,0000 \\
PD & - & - & 0,000000 & 0,0957 \\
ST & & & & \\
\hline
\end{tabular}

1.b. Wald Testi Sonucu

\begin{tabular}{llll}
\hline Wald Test: & & & \\
Test İstatistik & Değer & Derece & Olasılık \\
\hline F-istatistik & 382,0571 & $(4,57)$ & 0,0000 \\
X & 1528,228 & 4 & 0,0000 \\
\hline Boş Hipotezi: $C(4)=C(5)=C(6)=C(7)=0$ & & \\
\hline Boş Hipotezi Özeti: & & \\
\hline Normalleştirilmiş Kısıtlama (=0) & Değer & Standart \\
& & Hata \\
\hline$C(4)$ & 2,742159 & 0,156272 \\
$C(5)$ & 2,710665 & 0,155011 \\
$C(6)$ & 0,852888 & 0,156343 \\
$C(7)$ & 3,178056 & 0,157550 \\
\hline
\end{tabular}


Eskişehir Osmangazi Üniversitesi iiBF Dergisi

Ek-2

Yatay Kesit Bağımlılığı Testi Sonuçları

\begin{tabular}{lcr}
\hline Test & İstatistik & \multicolumn{1}{c}{ Olasılık } \\
\hline Breusch-Pagan LM & 44,77724 & 0,0000 \\
Pesaran Scaled LM & 11,19402 & 0,0000 \\
Pesaran CD & 51,63006 & 0,0000 \\
\hline
\end{tabular}

